\title{
Plastic ingestion by sea turtles in Paraíba State, Northeast Brazil
}

\author{
Camila Poli ${ }^{1,2}$, Daniel Oliveira Mesquita ${ }^{1}$, Cinthia Saska ${ }^{1,2} \&$ Rita Mascarenhas ${ }^{1,2}$
}

\begin{abstract}
1. Departamento de Sistemática e Ecologia, Centro de Ciências Exatas e da Natureza, Universidade Federal da Paraíba - UFPB, Cidade Universitária, Castelo Branco, 58059-900 João Pessoa, PB, Brazil. (camilapoli.cp@gmail.com; danmesq@dse.ufpb.br; cinthiasaska@yahoo.com.br; rita.mascarenhas@gmail.com) 2. Associação Guajiru: Ciência - Educação - Meio Ambiente - Projeto Tartarugas Urbanas, Av. Litorânea, Intermares, $58310-000$ Cabedelo, PB, Brazil.
\end{abstract}

\begin{abstract}
Currently, plastics are recognized as a major pollutant of the marine environment, representing a serious threat to ocean wildlife. Here, we examined the occurrence and effects of plastic ingestion by sea turtles found stranded along the coast of Paraíba State, Brazil from August 2009 to July 2010. Ninety-eight digestive tracts were examined, with plastic found in $20(20.4 \%)$. Sixty five percent $(\mathrm{n}=13)$ of turtles with plastic in the digestive tract were green turtles (Chelonia mydas), $25 \%(\mathrm{n}=5)$ were hawksbills (Eretmochelys imbricata), and $10 \%(\mathrm{n}=2)$ were olive ridley (Lepidochelys olivacea). More plastic was found in the intestine ( $85 \%$ ) than in other parts of the gastrointestinal tract. We observed complete blockage of the gastrointestinal tract due to the presence of plastic in 13 of the 20 turtles that had ingested plastic. No correlation was found between the curved carapace length (CCL) and the number or mass of the plastic ingested items. Significant differences were found between the intake of hard and soft plastic and the ingestion of white/transparent and colored plastic, with soft and white/transparent plastics being more commonly ingested. This study reveals the serious problem of plastic pollution to sea turtles at the area.
\end{abstract}

KEYWORDS. Marine debris ingestion, gastrointestinal blockage, Chelonia mydas, Eretmochelys imbricata, Lepidochelys olivacea.

RESUMO. Ingestão de plástico por tartarugas marinhas no estado da Paraíba, Nordeste do Brasil. Atualmente, os plásticos são reconhecidos como um dos principais poluentes do ambiente marinho, representando uma séria ameaça para a vida marinha. Neste trabalho, nós examinamos a ocorrência e os efeitos da ingestão de plástico por tartarugas marinhas encontradas encalhadas ao longo da costa do estado da Paraíba, Brasil, de agosto de 2009 a julho de 2010. Noventa e oito tratos gastrointestinais foram examinados e plásticos foram encontrados em 20 (20,4\%). Sessenta e cinco por cento $(\mathrm{n}=13)$ das tartarugas com plástico no trato gastrointestinal eram da espécie verde (Chelonia mydas), 25\% $(\mathrm{n}=5)$ eram da espécie pente (Eretmochelys imbricata) e 10\% $(\mathrm{n}=2)$ eram da espécie oliva (Lepidochelys olivacea). Foi encontrado mais plástico no intestino (85\%) do que em outras partes do trato gastrointestinal. Observou-se o completo bloqueio do trato gastrointestinal, devido à presença de plástico, em 13 das 20 tartarugas que ingeriram plástico. Não foi encontrada correlação entre o comprimento curvilíneo de carapaça (CCC) e o número ou massa dos itens plásticos ingeridos. Diferenças significativas foram encontradas entre a ingestão de plástico rígido e flexível e entre a ingestão de plástico branco/ transparente e colorido, com os flexíveis e brancos/transparentes sendo ingeridos com mais frequência. Este estudo revelou o grave problema da poluição por resíduos plásticos para as tartarugas marinhas nesta área.

PALAVRAS-CHAVE. Ingestão de lixo marinho, bloqueio gastrointestinal Chelonia mydas, Eretmochelys imbricata, Lepidochelys olivacea.

Sea turtles face a number of anthropogenic threats associated with marine pollution including trash, oil spills and the bioaccumulation of chemicals (HUTCHINSON \& Simmonds, 1992). Plastics are currently recognized as one of the most important pollutants in marine and coastal environments, and are reported in many studies as the main type of anthropogenic debris found in these habitats (IVAR Do Sul \& COSTA, 2007; SHEAVly \& REGISTER, 2007; RYAN et al., 2009). Estimates reveal that at least 5.25 trillions of plastic particles are currently floating in the sea, totaling 268,940 tons (ERIKSEN et al., 2014). Once in the environment, plastics can impact wildlife in a number of ways, including entanglement and ingestion (TourinHo et al., 2010). Plastic ingestion by seabirds, turtles, marine mammals, fishes, and invertebrates has been widely reported over the last decades (LAIST, 1997; STAMPER et al., 2006; Graham \& THOMPSON, 2009; SCHUYLER et al., 2012). Sea turtles are prone to this ingestion, which may occur when plastic items are mistaken for natural food such as jellyfish, or when items are accidentally ingested with food (LAIST, 1987; SCHUYLER et al., 2014).

The physical and chemical effects of plastic ingestion on sea turtles are widely recognized (MCCAULEY \& BJORNDAL, 1999; BUGONI et al., 2001; LAZAR \& GRAČAN,
2011). When ingestion levels are low, effects are generally sublethal, but can ultimately increase the probability of death (HutCHINSON \& SimmONDS, 1992). For example, nutritional dilution can occur when non-nutritious items occupy the food space in the gastrointestinal tract, affecting the nutritional gain and consequently growth and reproduction rates (MCCAULEY \& BJORNDAL, 1999). Related sublethal effects also include damage to the gastrointestinal tract such as necrosis and ulceration (BJORNDAL, 1997), and loss of buoyancy control due to the increased time food remains in intestinal tract compartments, accumulating gas in the intestine (GEORGE, 1997). Lethal effects occur when residues directly obstruct the digestive tract, blocking the passage of food (BJorndal et al., 1994; BUGONI et al., 2001; TOURINHO et al., 2010).

Northeastern Brazil is recognized as an important feeding and nesting area of at least four sea turtle species: hawksbill (Eretmochelys imbricata Linnaeus, 1766), loggerhead (Caretta caretta Linnaeus, 1758), olive ridley (Lepidochelys olivacea Eschscholtz, 1829), and green turtles (Chelonia mydas Linnaeus, 1758; MARCOVALDI \& Marcovaldi, 1999; Silva et al., 2007; Peres et al., 2011). Along the coast of Paraíba State, green turtles commonly use the reefs close to the shore as feeding 
grounds (MASCARENHAS et al., 2005), and hawksbills use the beaches for nesting (MASCARENHAS et al., 2003). Moreover, loggerhead, green, hawksbill and olive ridley turtle strandings have been recorded (MASCARENHAS et al., 2005; Mascarenhas \& Iverson, 2008).

In Brazil, the few studies that report plastic ingestion by sea turtles were conducted in the southern portion of the country (e.g., Bugoni et al., 2001; Tourinho et al., 2010). In Paraíba State, there is a single published record of plastic ingestion by one green and one olive ridley turtle (MASCARENHAS et al., 2004). Nevertheless, many unpublished records from the local project "Tartarugas Urbanas" indicate a possible increase of plastic ingestion by sea turtles that use waters adjacent to urbanized regions of the Paraíba coast. Given the low number of studies on how plastic ingestion affects sea turtles in northeastern Brazil and the importance of Paraíba state as a nesting and feeding ground, this study aims to analyze the effects of plastic ingestion on sea turtles along the coast of this state, registering the occurrence and possible lethal effects of this ingestion and providing valuable information for sea turtle conservation.

\section{MATERIALS AND METHODS}

This study was conducted from August 2009 to July 2010 on the coast of Paraíba State, northeastern Brazil, along $15 \mathrm{~km}$ of urban beaches in the municipalities of João Pessoa $\left(7^{\circ} 08^{\prime} \mathrm{S}\right.$ and $\left.34^{\circ} 48^{\prime} \mathrm{W}\right)$ and Cabedelo $\left(7^{\circ} 01^{\prime} \mathrm{S}\right.$ and $\left.34^{\circ} 49^{\prime} \mathrm{W}\right)$. We performed daily stranding surveys between Bessa beach ( $7^{\circ} 05^{\prime} \mathrm{S}$ and $\left.34^{\circ} 49^{\prime} \mathrm{W}\right)$ and Ponta de Campina beach $\left(7^{\circ} 01^{\prime} \mathrm{S}\right.$ and $34^{\circ} 49^{\prime} \mathrm{W}$, Fig. 1). For the remaining areas (Cabo Branco, Tambaú and Manaíra beaches, Fig. 1), stranding observations were communicated to us via a telephone line, "SOS Tartarugas". After communication by phone, we went to the stranding location to collect and record stranding data.

For each turtle stranded (dead or alive) we identified species and measured curved carapace length (CCL). Species were identified based on morphological characteristics according to international standards described in PrITCHARD \& MorTIMER (1999). We obtained CCL to an accuracy of $0.1 \mathrm{~cm}$ using a flexible measuring tape. Individuals were classified as juveniles or adults based on CCL measurements, with animals equal to or larger than the minimum CCL of nesting females on nearby beaches considered adults (see Grossman et al., 2007; Silva et al., 2007; SANTOS et al., 2010 for reference values). Live individuals were transported for rehabilitation under the care of the Tartarugas Urbanas project.

Carcasses that were not in advanced stages of decomposition were necropsied to sample the gastrointestinal tract. Gastrointestinal tracts were removed from the esophagus to the final portion of the intestine (WYNEKEN, 2001) and each segment was analyzed separately (esophagus, stomach and intestine). Gastrointestinal contents were manually extracted using tweezers and washed in tap water using sieves. When
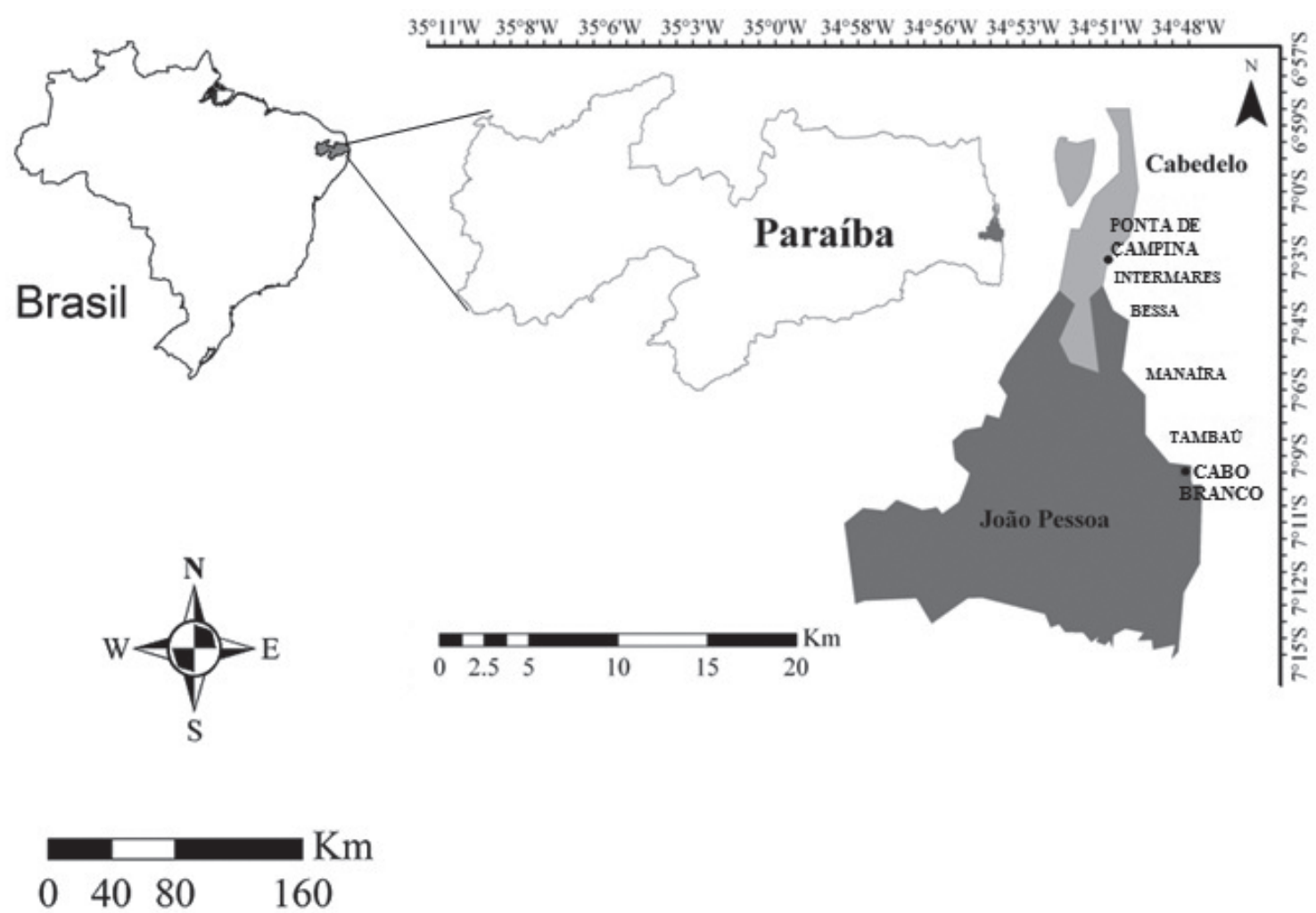

Fig. 1. Study area and monitored beaches in Cabedelo and João Pessoa Municipalities, Paraíba State, Brazil. 
present, plastics were separated from organic items, dried, measured, weighed, and classified according to their structure (soft or hard plastic) and color (colored or white/ transparent). Individuals that died during rehabilitation underwent the necropsy procedure described above.

The representativeness of ingested plastic types was recorded as frequency of occurrence (FO\%), as follows: $\mathrm{FO} \%=$ Number of animals that consumed the plastic type/ Total number of animals with plastic in their gastrointestinal tract * 100. The data used in statistical analysis that did not show normal distribution according to a D'AgostinoPearson's test were normalized using a Neperian log (AYRES et al., 2007). Pearson's correlations (AYres et al., 2007) were carried out between CCL and the amount (in numbers of pieces and total mass) of ingested plastic items. We performed a $t$-test for independent samples (AYres et al., 2007) to compare the composition of plastic items (type and color) in the gastrointestinal tract. For all statistical analysis, results were considered significant if $P<0.05$ (ZAR, 1999).

\section{RESULTS}

During the study period, 124 sea turtle strandings were recorded at the study area: 106 Green Turtles $(85.4 \%)$, 15 Hawksbill (12.1\%), two Olive Ridley (1.6\%) and one Loggerhead $(0.9 \%)$. Fifteen turtles $(12.1 \%)$ were stranded alive, but died during the rehabilitation period due to various complications, including plastic ingestion. We collected 98 gastrointestinal tracts based on decomposition of carcasses, being 84 Green Turtles, 12 Hawksbills and two Olive Ridley. Plastic residues were found in 13 Green Turtles $(15.5 \%$ - CCL range $29.1-85.6 \mathrm{~cm}$, mean $=44.15 \mathrm{~cm}, \mathrm{SD}$ $\pm 15.5 \mathrm{~cm}$ ), five Hawksbills (41.7\% - CCL range 29.6 - 89.3 $\mathrm{cm}$, mean $=44.68 \mathrm{~cm}, \mathrm{SD} \pm 25.09 \mathrm{~cm})$ and two Olive Ridley
$(100 \%$ - CCL range $60-63.3 \mathrm{~cm}$, mean $=61.65 \mathrm{~cm}, \mathrm{SD} \pm$ $2.33 \mathrm{~cm}$ ). Only one turtle (hawksbill, $\mathrm{CCL}=89.3 \mathrm{~cm}$ ) was classified as an adult. Among the 20 individuals with plastic in their gastrointestinal tract, $13(65 \%$ - nine green and four hawksbill turtles) had their tract blocked by plastic, which resulted in death. Among these 13 individuals, 10 were initially found alive but were debilitated and emaciated, indicating that they had not been feeding normally prior to stranding. Twelve individuals $(60 \%)$ had plastic only in the intestine, three $(15 \%)$ only in the stomach, and five $(25 \%)$ in both the stomach and intestine. We did not find plastic fragments in the esophagus of any turtle.

A total of 361 anthropogenic plastic items were ingested by all individuals, ranging from one up to 87 items per turtle $($ mean $=18.1, \mathrm{SD} \pm 20.4$ items, Tab. 1). The total mass of plastic in the gastrointestinal tracts among all turtles was $114.9 \mathrm{~g}$, ranging from $0.01 \mathrm{~g}$ to $63.5 \mathrm{~g} /$ individual (mean $=5.7 \mathrm{~g}, \mathrm{SD} \pm 14.1 \mathrm{~g}$ /individual; Tab. 1). Regarding the 13 turtles with blocked gastrointestinal tracts, the number and mass of plastic ranged from seven to 87 items per turtle and $0.1 \mathrm{~g}$ to $63.5 \mathrm{~g} /$ individual. We did not find a significant correlation between CCL and the number of ingested plastic items $(R=-0.15, P=0.5, \mathrm{n}=20)$, or between CCL and the mass of ingested plastic per turtle $(R=0.0182, P=0.9, \mathrm{n}=20)$. Most ingested items were soft plastics (310 items, $85.9 \%$; Tab. 1), with an average of $15.5( \pm 19)$ items per turtle. Hard plastics amounted to 51 items (14.1\%; Tab. 1), with an average of $2.5( \pm 4.4)$ items per turtle. We found significant difference between the number of soft and hard plastic ingested $(t=4.6, P=$ 0.0001 ; soft plastics $\mathrm{FO} \%=95 \%$, hard plastics $\mathrm{FO} \%=$ $50 \%$ ). There was also a significant difference between the number of white/transparent and colored plastics ingested $(t=-2.9 ; P=0.005)$. White/transparent plastics were more common, accounting for 258 items $(\bar{x}=12.9 \pm 16$ items

Tab. I. Raw data on plastics collected in the gastrointestinal tract of sea turtles in Cabedelo and João Pessoa Municipalities, Paraíba State, Brazil.

\begin{tabular}{|c|c|c|c|c|c|c|c|c|c|c|c|c|}
\hline \multirow{2}{*}{ Species } & \multirow{2}{*}{ CCL } & \multirow{2}{*}{ Items } & \multirow{2}{*}{ Mass (g) } & \multirow{2}{*}{$\begin{array}{c}\text { Soft } \\
\text { plastic }\end{array}$} & \multirow{2}{*}{$\begin{array}{c}\text { Hard } \\
\text { plastic }\end{array}$} & \multirow{2}{*}{$\begin{array}{c}\text { White/transparent } \\
\text { plastic }\end{array}$} & \multirow{2}{*}{$\begin{array}{l}\text { Colored } \\
\text { plastic }\end{array}$} & \multicolumn{5}{|c|}{ Color of plastic } \\
\hline & & & & & & & & Black & Blue & Green & Pink & Yellow \\
\hline $\mathrm{CM}$ & 29.1 & 26 & 4.65 & 25 & 1 & 24 & 2 & 1 & 0 & 0 & 1 & 0 \\
\hline $\mathrm{CM}$ & 29.9 & 10 & 1.23 & 8 & 2 & 8 & 2 & 2 & 0 & 0 & 0 & 0 \\
\hline $\mathrm{CM}$ & 33.7 & 14 & 1.39 & 11 & 3 & 10 & 4 & 2 & 0 & 0 & 1 & 1 \\
\hline $\mathrm{CM}$ & 35.2 & 7 & 0.57 & 7 & 0 & 5 & 2 & 1 & 1 & 0 & 0 & 0 \\
\hline $\mathrm{CM}$ & 36 & 8 & 0.16 & 8 & 0 & 8 & 0 & 0 & 0 & 0 & 0 & 0 \\
\hline $\mathrm{CM}$ & 37 & 1 & 0.01 & 1 & 0 & 0 & 1 & 0 & 1 & 0 & 0 & 0 \\
\hline $\mathrm{CM}$ & 39.1 & 5 & 0.34 & 5 & 0 & 5 & 0 & 0 & 0 & 0 & 0 & 0 \\
\hline $\mathrm{CM}$ & 41.3 & 15 & 0.33 & 15 & 0 & 15 & 0 & 0 & 0 & 0 & 0 & 0 \\
\hline $\mathrm{CM}$ & 43.6 & 8 & 0.11 & 8 & 0 & 5 & 3 & 0 & 2 & 1 & 0 & 0 \\
\hline $\mathrm{CM}$ & 47.5 & 2 & 0.11 & 2 & 0 & 2 & 0 & 0 & 0 & 0 & 0 & 0 \\
\hline $\mathrm{CM}$ & 55.4 & 17 & 6.03 & 13 & 4 & 11 & 6 & 4 & 1 & 1 & 0 & 0 \\
\hline $\mathrm{CM}$ & 60.5 & 1 & 0.33 & 1 & 0 & 1 & 0 & 0 & 0 & 0 & 0 & 0 \\
\hline $\mathrm{CM}$ & 85.6 & 87 & 63.53 & 84 & 3 & 73 & 14 & 10 & 2 & 2 & 0 & 0 \\
\hline EI & 30.9 & 40 & 9.96 & 30 & 10 & 20 & 20 & 13 & 2 & 5 & 0 & 0 \\
\hline EI & 31 & 35 & 1.9 & 32 & 3 & 8 & 27 & 1 & 0 & 26 & 0 & 0 \\
\hline EI & 35 & 35 & 9.22 & 31 & 4 & 22 & 13 & 4 & 8 & 1 & 0 & 0 \\
\hline EI & 37.2 & 31 & 12.74 & 13 & 18 & 23 & 8 & 3 & 0 & 3 & 2 & 0 \\
\hline EI & 89.3 & 12 & 0.37 & 12 & 0 & 12 & 0 & 0 & 0 & 0 & 0 & 0 \\
\hline LO & 60 & 4 & 0.13 & 4 & 0 & 4 & 0 & 0 & 0 & 0 & 0 & 0 \\
\hline LO & 63.3 & 3 & 1.81 & 0 & 3 & 2 & 1 & 0 & 0 & 1 & 0 & 0 \\
\hline
\end{tabular}


per turtle; $\mathrm{FO}^{2}=95 \%$; Tab. 1). Colored plastics (black, blue, green, red and yellow) accounted for 103 items ( $\bar{x}$ $=5.1 \pm 7.6$ per turtle; $\mathrm{FO} \%=65 \%$; Tab. 1 ).

\section{DISCUSSION}

All sea turtles species are prone to the ingestion of plastic, which may occur accidentally, when these residues are confused with their natural foods such as jellyfish, or when they are ingested with food (MrosovsKy et al., 2009; SCHUYLER et al., 2014). In previous studies, Green Turtles were the main species ingesting plastic (BUGONI et al., 2001; TOURINHO et al., 2010; GUEBERT-BARTHOLO et al., 2011), but in this study, proportionally, the plastic ingestion incidence was higher in Hawksbills turtles. . Probably, the predominant number of Green Turtles in the present study was due to the fact this species use the coral reefs of the Paraíba coast as a feeding ground (MASCARENHAS et al., 2005), favoring their stranding in the study area. Green turtles may be especially prone to plastic ingestion, since this type of debris is commonly found adhered to their main food resource, algae (REIs et al., 2010), but SCHUYLER et al., (2012) not found significant difference in the plastic ingestion between Green and Hawksbill species. Both species, exhibit similar feeding behavior, with smaller turtles feeding pelagically, and larger turtles shifting to benthic feeding (BJORNDAL, 1997). We did not find a correlation between CCL and the number or mass of ingested plastic items, which is consistent with other studies (BUGONI et al., 2001; TOURINHO et al., 2010; LAZAR \& GRAČAN, 2011). Although some studies have suggested that juveniles are more prone to plastic ingestion (BALAZS, 1985; BJORNDAL, 1997; SCHUYLER et al., 2012); however, we can not presume the same, since in this study only one adult animal was observed.

Our study showed a lower plastic ingestion rate for Green Turtles when compared to previous works (BUGONI et al., 2001; TOURINHO et al., 2010; GUEBERT-BARTHOLO et al.,
2011; see Tab. 2). Perhaps this lower ingestion rate observed for green turtles is related to a lower availability of plastic in the feeding grounds of these populations. Nonetheless, our most important finding in terms of conservation involves the lethal effects of plastic ingestion observed in stranded sea turtles. Previous studies have reported a low occurrence of sea turtle deaths related to plastic ingestion (PLOTKIN et al., 1993; MrosovsKy et al., 2009; GUEBERT-BARTHOLO et al., 2011), with some authors assuming that death caused by plastic blockage of the intestine is only occasional (Tomás et al., 2002; Mrosovsky et al., 2009). Here we report a relatively large number of sea turtles deaths caused by plastic ingestion (Tab. 2), and higher amounts and mass of plastic items ingested by individual turtles than those mentioned in other works (BUGONI et al., 2001; LAZAR \& GRAČAN, 2011). However, the plastic mass found in turtles with blocked gastrointestinal tracts was smaller (BJORNDAL et al., 1994; BUGONI et al., 2001; LAZAR \& GRAČAN, 2011). BJORNDAL et al. (1994) reports that turtles can die with just a small amount of plastic in their gastrointestinal tract, which in their study ranged from 2.2 to $6.5 \mathrm{~g}$ ).

In the present study we examined the entire gastrointestinal tracts, and found that plastics were most common in the intestines of turtles. Most works reporting plastic ingestion have been associated with dietary studies, frequently using only the contents of the esophagus and stomach that likely underestimates plastic ingestion. Other studies have also indicated that the intestines hold a larger amount of plastic than the esophagus and stomach (BJorndal et al., 1994; Tomás et al., 2002). We suggest that future studies evaluate the entire gastrointestinal tract of turtles, so we can get more reliable estimates.

White/transparent plastic items were ingested significantly more frequently than colored plastic items. Previous studies also reported a higher ingestion of white/transparent plastic (BUGONI et al., 2001; LAZAR \& GRAČAN, 2011; SCHUYLER et al., 2014). CARR (1987) and GRAMENTZ (1988) attribute the higher frequency of white/transparent plastic ingestion to the fact that turtles

Tab. II. Occurrence of plastic ingestion by sea turtles and lethal cases related with this ingestion based on literature data and present study [CM, Chelonia mydas; CC, Caretta caretta; DC, Dermochelys coriacea (Vandelli, 1761); EI, Eretmochelys imbricata; LK, Lepidochelys kempii; LO, Lepidochelys olivacea].

\begin{tabular}{|c|c|c|c|c|c|}
\hline Study area & $\begin{array}{c}\text { Occurrence of ingestion } \\
\text { by species } n(\%)\end{array}$ & $\begin{array}{l}\text { Total occurrence of } \\
\text { ingestion } n(\%)\end{array}$ & $\begin{array}{l}\text { Lethal cases } \\
\text { by species }\end{array}$ & $\begin{array}{l}\text { Total of } \\
\text { lethal cases }\end{array}$ & Reference \\
\hline Northwestern Gulf of Mexico & $\mathrm{CC}=-(51.2 \%)$ & $(51.2 \%)$ & $\mathrm{CC}=3$ & 3 & PlotKIn et al.,1993 \\
\hline Adriatic Sea & $\mathrm{CC}=19(35.2 \%)$ & $19(35.2 \%)$ & $\mathrm{CC}=1$ & 1 & LAZAR \& GRAČAN, 2011 \\
\hline Western Mediterranean & $\mathrm{CC}=43(79.6 \%)$ & $43(79.6 \%)$ & 0 & 0 & ToмÁs et al., 2002 \\
\hline Southern Brazil & $\mathrm{CM}=-(69.7 \%)$ & $(69.7 \%)$ & $\mathrm{CM}=3$ & 3 & GuEBERT-BARTHOLO et al., 2011 \\
\hline Southern Brazil & $\begin{array}{c}\mathrm{CM}=23(60.5 \%) \\
\mathrm{CM}=24(56 \%)\end{array}$ & $23(60.5 \%)$ & $\mathrm{CM}=4$ & 4 & BUGONI et al., 2001 \\
\hline Florida Coast & $\begin{array}{c}\mathrm{CC}=1(100 \%) \\
\mathrm{LK}=0\end{array}$ & $25(49 \%)$ & - & 2 & BJORNDAL et al., 1994 \\
\hline Southern Brazil & $\mathrm{CM}=34(100 \%)$ & $34(100 \%)$ & $\mathrm{CM}=3$ & 3 & TOURINHO et al., 2010 \\
\hline Multiple areas & $\mathrm{DC}=138(33.8 \%)$ & $138(33.8 \%)$ & $\mathrm{DC}=12$ & 12 & MrosovsKy et al., 2009 \\
\hline Paraíba Coast & $\begin{array}{c}\mathrm{CM}=13(15.5 \%) \\
\mathrm{EI}=5(41.7 \%) \\
\mathrm{LO}=2(100 \%)\end{array}$ & $20(20.4 \%)$ & $\begin{array}{c}\mathrm{CM}=9 \\
\mathrm{EI}=4\end{array}$ & 13 & This study \\
\hline
\end{tabular}


mistake this color of plastic with jellyfish, which is a common item in the diet of some sea turtle species. Green and loggerhead turtles maintained in captive conditions will ingest plastics that are either colored (blue, yellow, pink) or white/transparent, with the former ingested less frequently (LUTZ, 1990). SCHUYLER et al., 2014 suggested that sea turtles consume less blue plastics because they can be less visible in the open water background where they forage. Soft plastic was the most common kind of plastic found in our study, corroborating the results of previous studies (TOURINHO et al., 2010; LAZAR \& GRAČAN, 2011; SCHUYLER et al., 2014). The main hypothesis supported is that the turtles select debris similar to your food type, such as jellyfish, but the plastic availability in the feeding substrate of these populations should also be considered. However, the availability of type and color of plastic in the coastal area of Paraíba is still unknown, and it is therefore not possible to evaluate if white and soft plastics were selected in greater proportion than their availability in the environment. However, specific studies in these areas are needed in order to test the hypothesis. Our results reveal for the first time the serious threat to sea turtles in Northeastern Brazil. We observed that sea turtles at the Paraíba coast ingest plastic in large amounts, resulting in high mortality level. These data indicate that coastal habitats used by sea turtles in this region are contaminated with plastic, and that the consequences of plastic ingestion may be severe. Effective measures to minimize plastic pollution are needed to contribute towards the conservation of sea turtles and others species. More studies are required to determine whether the high percentage of deaths we found to be associated with the ingestion of plastic is just an isolated case, or if this is a consistent and perhaps increasing problem in northeast Brazil. Additional studies are also needed to determine the sublethal effects of plastic ingestion, such as the absorption of toxins through the intestine and its consequences, as well as specific studies quantifying the amount of plastic in this environment.

Acknowledgements. We would like to thank the entire volunteer team of Projeto Tartarugas Urbanas (Associação Guajiru) for their help in field work, the Coordenação de Aperfeiçoamento de Pessoal de Nível Superior (CAPES) for their financial support, CNPq for a research fellowship for D.O. Mesquita, and the Programa de Pós-graduação em Ciências Biológicas, Universidade Federal da Paraíba for supporting this study.

\section{REFERENCES}

Ayres, M.; Ayres JR., M.; Ayres, D. L. \& SAntos, A. A. S. 2007. BioEstat: Aplicações estatísticas nas áreas das ciências biológicas e médicas, versão 5.0. Belém, Mamirauá/MCT SC.

BALAZS, G. 1985. Impact of ocean debris on marine turtles: entanglement and ingestion. In: Shomura, R. S. \& Yoshida, H. O. eds. Proceedings of the Workshop on the Fate and Impact of Marine Debris, 27-29 November 1984, Honolulu, Hawaii. Honolulu, Southwest Fisheries Center, Honolulu Laboratory, National Marine Fisheries Service, p. 387-429.

BJORNDAL, K. A. 1997. Foraging ecology and nutrition of sea turtles. In: Lutz, P. L. \& Musick, J. A. eds. The Biology of Sea Turtles. Boca Raton, CRC Press, p. 199-231.
Bjorndal, K. A.; Bolten, A. B. \& Lagueux, C. J. 1994. Ingestion of marine debris by juvenile sea turtles in coastal Florida habitats. Marine Pollution Bulletin 28:154-158.

Bugoni, L.; Krause, L. \& Petry, M. V. 2001. Marine debris and human impacts on sea turtles in southern Brazil. Marine Pollution Bulletin 42:1330-1334.

CARR, A. 1987. Impact of nondegradable marine debris on the ecology and survival outlook of sea turtles. Marine Pollution Bulletin 18(6) Supplement B:352-356.

Eriksen, M.; Lebreton, L. C. M.; Carson, H. S.; Thiel, M.; Moore, C. J. \& Borerro, J. C. 2014. Plastic Pollution in the World's Oceans: More than 5 Trillion Plastic Pieces Weighing over 250,000 Tons Afloat at Sea. PLoS ONE 9(12): E111913.

George, R. H. 1997. Health problems \& diseases of sea turtles. In: LutZ, P. L. \& Musick, J. A. eds. The Biology of Sea Turtles. Boca Raton, CRC Press, p. 363-385.

Graham, E. R. \& Thompson, J. T. 2009. Deposit and suspension-feeding sea cucumbers (Echinodermata) ingest plastic fragments. Journal of Experimental Marine Biology and Ecology 368:22-29.

Gramentz, D. 1988. Involvement of loggerhead turtle with the plastic, metal, and hydrocarbon pollution in the central Mediterranean. Marine Pollution Bulletin 19:11-13.

Grossman, A.; Mendonça, P.; Costa, M. R. \& Bellini, C. 2007. Morphometrics of the green turtle at the Atol das Rocas Marine Biological Reserve, Brazil. Marine Turtle Newsletter 118:12-13.

Guebert-Bartholo, F.; Barletta, M.; Costa, M. \& Monteiro-Filho, E. 2011. Using gut contents to assess foraging patterns of juvenile green turtles Chelonia mydas in the Paranaguá; Estuary, Brazil. Endangered Species Research 13:131-143.

Hutchinson, J. \& Simmonds, M. 1992. Escalation of threats to marine turtles. Oryx 26:95-102.

Ivar do Sul, J. A. \& Costa, M. F. 2007. Marine debris review for Latin America and the wider Caribbean region: From the 1970s until now, and where do we go from here? Marine Pollution Bulletin 54:1087-1104.

Jambeck, J. R.; Andrady, A.; Geyer, R.; Narayan, R.; Perryman, M.; Siegler, T.; Wilcox, C. \& Lavender LaW, K. (2015). Plastic waste inputs from land into the ocean, Science 347:768-771.

LAIST, D. W. 1987. Overview of the biological effects of lost and discarded plastic debris in the marine-environment. Marine Pollution Bulletin 18:319-326.

1997. Impacts of marine debris: entanglement of marine life in marine debris including a comprehensive list of species with entanglement and ingestion records. In: COE, J. M. \& RoGERS, D. B. eds. Marine Debris: Sources, Impacts and Solutions. New York, Springer-Verlag, p. 99-140.

LAZAR, B. \& GRAČAN, R. 2011. Ingestion of marine debris by loggerhead sea turtles, Caretta caretta, in the Adriatic Sea. Marine Pollution Bulletin 62:43-47.

LutZ, P.L. 1990. Studies on the ingestion of plastic and latex by sea turtles. In: Shomura, R. S. \& Yoshida, H.O. eds. Proceedings of the Workshop on the Fate and Impact of Marine Debris, 27-29 November 1984, Honolulu, Hawaii. Honolulu, Southwest Fisheries Center, Honolulu Laboratory, National Marine Fisheries Service, p. 719-735.

Marcovaldi, M. A. \& Marcovaldi, G. G. 1999. Marine turtles of Brazil: the history and structure of Projeto TAMAR-IBAMA. Biological Conservation 91:35-41.

Mascarenhas, R. \& Iverson, P. J. 2008. Fibropapillomatosis in Stranded Green Turtles (Chelonia mydas) in Paraiba State, Northeastern Brazil: Evidence of a Brazilian Epizootic? Marine Turtle Newsletter 120:3-6.

Mascarenhas, R.; Santos, R. \& Zeppelini, D. 2004. Plastic debris ingestion by sea turtle in Paraíba, Brazil. Marine Pollution Bulletin 49:354-355.

2005. Stranded sea turtles on the coast of Paraíba, Brazil. Marine Turtle Newsletter 107:13-14.

Mascarenhas, R.; ZePPelini, D. \& Moreira, V. S. 2003. Observations on sea turtles in the State of Paraíba, Brazil. Marine Turtle Newsletter 101:16-18. 
McCauley, S. J. \& Buorndal, K. A. 1999. Conservation implications of dietary dilution from debris ingestion: sublethal effects in posthatchling Loggerhead Sea Turtles. Conservation Biology 13:925929.

Mrosovsky, N.; RyAn, G. D. \& JAmEs. M. C. 2009. Leatherback turtles: the menace of plastic. Marine Pollution Bulletin 58:287-289.

Peres, M. B.; Magris, R. A. \& Ribeiro, K. T. 2011. Número temático avaliação do estado de conservação das tartarugas marinhas apresentação. Biodiversidade Brasileira 1:1-2.

Plotkin, P. T.; Wicksten, M. K. \& Amos, A. F. 1993. Feeding ecology of the loggerhead sea turtle Caretta caretta in the Northwestern Gulf of Mexico. Marine Biology 115:1-5.

Pritchard, P. C. H. \& Mortimer, J. A. 1999. Taxonomy, external morphology and species identification. In: ECKERT, K. L.; BJORNDAL, K. A.; Abreu-Grobois, F. A. \& Donelly, M. eds. Research and Management Techniques for the Conservation of Sea Turtles. Washington DC, IUCN/SSC Marine Turtle Specialist Group Publication, p. 21-40.

Reis, E. C.; Pereira, C. S.; Rodrigues, D. D. P.; Secco, H. K. C.; Lima, L. M.; Rennó, B. \& Siciliano, S. 2010. Condição de saúde das tartarugas marinhas do litoral Centro-Norte do Estado do Rio de Janeiro, Brasil: Avaliação sobre a presença de agentes bacterianos, fibropapilomatose e interação com resíduos antropogênicos. Oecologia Australis 14(3):756-765.

Ryan, P.; Moore, C.; Franeker, J. van \& Moloney, C. 2009. Monitoring the abundance of plastic debris in the marine environment. Philosophical Transactions of the Royal Society B: Biological Sciences 364:1999-2012.

Santos, A. J. B.; Freire, E. M. X.; Bellini, C. \& Corso, G. 2010. Body mass and the energy budget of gravid Hawksbill Turtles (Eretmochelys imbricata) during the nesting season. Journal of Herpetology 44:352-359.
Schuyler, Q.; Hardesty, B.D.; Wilcox, C. \& Townsend, K. 2012. To Eat or Not to Eat? Debris Selectivity by Marine Turtles. PLoS ONE 7(7):0040884.

Schuyler, Q.; Wilcox, C.; Townsend, K.; Hardesty, B. D. \& Marshall, N. J. 2014. Mistaken identity? Visual similarities of marine debris to natural prey items of sea turtles. BMC Ecology 14:14.

Sheavly, S. \& Register, K. 2007. Marine debris \& plastics: environmental concerns, sources, impacts and solutions. Journal of Polymers and the Environment 15:301-305.

Silva, A. C. C. D.; Castilhos, J. C.; Lopez, G. G. \& Barata, P. C. R. 2007. Nesting biology and conservation of the Olive Ridley sea turtle (Lepidocheyls olivacea) in Brazil, 1991/1992 to 2002/2003. Journal of the Marine Biological Association of the United Kingdom 87:1047-1056.

Stamper, M. A.; Whitaker, B. R. \& Schofield, T. D. 2006. Case study: Morbidity in a pygmy sperm whale Kogia breviceps due to oceanbourne plastic. Marine Mammal Science 22:719-722.

Tomás, J.; Guitart, R.; Mateo, R. \& Raga, J. A. 2002. Marine debris ingestion in Loggerhead sea turtles, Caretta caretta, from the Western Mediterranean. Marine Pollution Bulletin 44:211-216.

Tourinho, P. S.; Ivar do Sul, J. A. \& Fillmann, G. 2010. Is marine debris ingestion still a problem for the coastal marine biota of southern Brazil? Marine Pollution Bulletin 60:396-401.

Wyneken, J. 2001. The anatomy of sea turtles. Miami, Southeast Fisheries Science Center, National Marine Fisheries Service, National Oceanic and Atmospheric Administration, U.S. Dept. of Commerce. $172 \mathrm{p}$.

ZAR, J. H. 1999. Biostatistical Analysis. New Jersey, Prentice-Hall. 663p. 